\title{
Standard and Light-Cycler PCR methods for animal DNA species detection in animal feedstuffs
}

\author{
Domenico Frezza $^{\mathrm{a}, *}$, Vincenzo Giambra ${ }^{\mathrm{a}}$, Fatima Chegdani ${ }^{\mathrm{b}}$, Cecilia Fontana ${ }^{\mathrm{b}}$, \\ Giampietro Maccabiani ${ }^{\mathrm{c}}$, Nadia Losio ${ }^{\mathrm{c}}$, Elena Faggionato ${ }^{\mathrm{c}}$, Barbara Chiappini ${ }^{\mathrm{d}}$, \\ Gabriele Vaccari ${ }^{\mathrm{d}}$, Christoph von Holst ${ }^{\mathrm{e}}$, Luigi Lanni ${ }^{\mathrm{f}}$, \\ Stefano Saccares ${ }^{\mathrm{f}}$, Paolo Ajmone-Marsan ${ }^{\mathrm{b}}$ \\ a Department di Biologia "Enrico Calef" Università di Roma Tor Vergata, Italy \\ ${ }^{\mathrm{b}}$ Istituto di Zootecnica, Università Cattolica del S. Cuore, Piacenza. Italy \\ ' Istituto Zooprofilattico Sperimentale della Lombardia e dell'Emilia-Romagna, Brescia, Italy \\ ${ }^{\mathrm{d}}$ Istituto Superiore di Sanità, Department of Food Safety and Veterinary Public Health, Rome, Italy

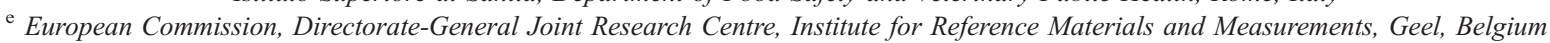 \\ ${ }^{\mathrm{f}}$ Istituto Sperimentale Zooprofilattico della Toscana e del Lazio, Italy
}

Received 15 August 2006; accepted 14 April 2007

\begin{abstract}
In this work four species-specific primers and probes were designed and evaluated for the detection and quantification of bovine, ovine, swine and chicken mitochondrial DNA in feeds. PCR primers were optimized using conventional and Real Time PCR, to detect short species-specific sequences amplifiable from heat treated material. Both methods confirmed the high specificity of the primers designed. Real time quantitative PCR assay allowed the detection of as few as $0.01 \mathrm{ng}$ and $0.05 \mathrm{ng}$ of ovine and bovine genomic DNA, respectively. The detection limit for swine and chicken genomic DNA was $0.5 \mathrm{ng}$. Sensitivity levels observed in DNA extracted from meat samples processed according to EU legislation were different compared to those in genomic DNAs previously described. They resulted in swine 5 fg of MBM DNA, in chicken 25 ng, in ovine and bovine $50 \mathrm{ng}$. We confirmed the efficiency and specificity of primers in RT-PCR to detect $0.5 \%$ of bovine, ovine, swine and chicken MBM in contaminated feedstuffs.
\end{abstract}

(C) 2007 Elsevier Ltd. All rights reserved.

Keywords: BSE prophylaxis; Rendering material; Species-specific primers; Quantitative real time PCR

Industrial relevance: The variant Creutzfeldt Jakob disease is a rare and fatal human neurodegenerative condition clearly linked with the bovine spongiform encephalopathies (BSE) of cattle. The ban of using animal derived protein in animal feeds has efficiently controlled the development of the BSE epidemic. The work presented by Frezza and collaborators is an application of the real time polymerase chain reaction (a standard procedure used in molecular biology also known as RTPCR) to identify specific DNA of four animal species (bovine, ovine, swine and chicken). This method is applied to the analysis of feeds to detect and eventually estimate the amount of animal derived proteins. The difficult aim to detect DNA derived from heat-treated material was successfully reached using as target short mitochondrial DNA sequences. The method presented could have important application not only in the control of feed production but also in many fields of the food industry as quality and process control.

\footnotetext{
* Corresponding author. Department of Biology “Enrico Calef” University of Roma Tor Vergata, viale della Ricerca Scientifica, 00133 Roma, Italy. Tel.: +39 06 72594814; fax: +39062023500.

E-mail address: frezza@uniroma2.it (D. Frezza).
}

\section{Introduction}

Bovine Spongiform Encephalopathy (BSE) was spread through animal feed containing infected meat and bone meal (MBM) (BSE Inquiry, 2000a, vol 1 and BSE Inquiry, 2000b vol 2). The BSE epidemic first recognized in the UK in 1986 reached most of the European countries. To date 187,000 case of 
the disease have been reported in cattle with more than $98 \%$ in the UK (http://www.oie.int). Immediately, procedures had to be implemented to avoid the risk of contamination with infected material and intraspecies recycling. Accordingly, the European Union (EU) introduced restrictions in the production and use of MBM for feeding ruminants and other species of farm animals (Commission Decision 94/381/EC of 27 June, 1994; Commission Decision 94/382/EC of 27 June, 1994; EC (2002) Regulation 1774/2002). Since then, a considerable research effort has been directed towards the development of simple, reliable, high sensibility and low-cost analytical methods to detect MBM in animal feed, to avoid fraud and accidental contamination (see Gizzi et al., 2003 for a review). The first PCR application in MBM detection was reported by Tartaglia et al. (1998). Thereafter, a number of investigations have demonstrated the utility of this technology in the detection and identification of species-specific components in MBM and feedstuffs (Krcmar \& Rencova, 2001; Momcilovic \& Rasooly, 2000; Myers et al., 2006; Yancy, Mohla, Farrell, \& Myers, 2005). PCR methods in fact reach precision and sensitivity levels difficult to achieve using microscopic examination, or impossible applying immuno-enzymatic assays, because of protein instability in heattreated material (Ansfield, Reaney, \& Jackman, 2000; Baeten et al., 2005; Kim et al., 2005). Attempts to establish multiplex PCR (Dalmasso et al., 2004) and real time PCR (RT-PCR) protocols in contaminated food and feedstuff have recently been reported (Krcmar and Rencova, 2005; Lopez-Andreo, Lugo, GarridoPertiera, Prieto, \& Puyet, 2005; Mendoza-Romero et al., 2004; Taurai, Schumacher, \& Roger, 2005). Compared to conventional PCR, RT-PCR has the advantage of quantifying the small size products (from 66 to $145 \mathrm{bp}$ ), amplified from highly degraded source material, like rendered MBM. Recently (Frezza et al., 2003), we demonstrated that short amplicons can be used to detect the presence of bovine mitochondrial DNA (mtDNA) in MBM samples treated according to the current European legislation (133 ${ }^{\circ} \mathrm{C}, 20^{\prime}, 3$ bars) (Dept. of Agr., Food and Rur. Develop. http://www.irlgov.ie/daff/bse/bse.htm). While potentially offering a very sensitive method for the quantification of specific DNA targets, RT-PCR can produce biased results if applied to DNA concentrations outside the linear range of detection that varies from material to material and amplicon to amplicon. In this paper, we tested the performance of Light-
Cycler RT-PCR using species-specific primers and probes to detect and quantify in feedstuffs bovine, ovine, swine and chicken MBM treated according to EU legislation.

\section{Materials and methods}

\subsection{Samples preparation}

To prepare MBM from different species, bovine, ovine, swine and chicken meat was chopped at a maximum particle size of $50 \mathrm{~mm}$, autoclaved at $133{ }^{\circ} \mathrm{C}$ for $20^{\prime}$ at a pressure of 3 bar (von Holst, Unglaub, \& Anklam, 2001) and lyophilised. Commercial feedstuffs samples were contaminated by mixing bovine, ovine, swine and chicken MBM to $100 \mathrm{~g}$ of ground material, at final percentage of $0.2 \%, 0.5 \%$ and $1 \%$ MBM.

Genomic DNA of samples isolated from tissue and blood from different species, Bos taurus, Sus scrofa, Gallus gallus, Ovis aries, was used as positive control. Genomic DNA from mouse, dog, goat, buffalo, deer, horse and wild boar was used as negative control.

\subsection{DNA extraction}

Total DNA was extracted from $200 \mathrm{mg}$ of meat, MBM and MBM contaminated feedstuffs using Wyzard Magnetic DNA purification system for food (Promega, California, USA), according to manufacturer instructions. DNA concentration was measured by spectrophotometric analysis (Biophotomer,Eppendorf, Germany).

\subsection{Primer and probe design}

Species-specific primers were designed for the detection of bovine, ovine, swine and chicken DNA (Table 1). Sequences of different mtDNA genes were extracted from GenBank database (http://www.ncbi.nlm.nih.gov) and aligned using Clustal W software (http://www.ch.embnet.org/software/ClustalW.html). Regions showing a low level of intra-species polymorphism and a relatively high degree of divergence among the species investigated were selected to design species-specific primer pairs, amplifying products shorter than $120 \mathrm{bp}$. To be used in RT-PCR, forward primers in B. taurus, S. scrofa, G. gallus and

Table 1

Species-specific primer, LC probe sequences and amplification conditions

\begin{tabular}{|c|c|c|c|c|c|}
\hline Specie & $\begin{array}{l}\text { Primers } \\
\left(5^{\prime}-3^{\prime}\right)\end{array}$ & $\begin{array}{l}\text { Probes } \\
\left(5^{\prime}-3^{\prime}\right)\end{array}$ & $\begin{array}{l}\text { Annealing } \\
\text { temperature }\end{array}$ & Target & $\begin{array}{l}\text { Size } \\
(\mathrm{bp})\end{array}$ \\
\hline \multicolumn{6}{|l|}{ Bos } \\
\hline taurus & $\begin{array}{l}\text { f-CTTGAACTAGACCTAGCCCAAAGATAC } \\
\text { r-ATAGCGCCGTACTTAGATTTCTATCTCC }\end{array}$ & GTTTTATTCTATCTTGGTTGTTTAGTCGAAG & $58^{\circ} \mathrm{C} / 6 \mathrm{~s}$ & $16 \mathrm{~S}$ rRNA & 112 \\
\hline $\begin{array}{l}\text { Sus } \\
\qquad \text { scrofa }\end{array}$ & $\begin{array}{l}\text { f-ATGACCAACATCCGAAAATCAC } \\
\text { r-TGCCTAAGAGGGAACCGAAG }\end{array}$ & GCGTTGTTGATAATTTTTATTAGTGGG & $52^{\circ} \mathrm{C} / 8 \mathrm{~s}$ & Cytocrhom b & 114 \\
\hline $\begin{array}{l}\text { Ovis } \\
\quad \text { aries }\end{array}$ & $\begin{array}{l}\text { f-CTTGAACTATACCTAGCCCAAAAT } \\
\text { r-ATAGCGCCGTGTTTAGAATTTCTATC }\end{array}$ & AATTAAAATAAAACATTTACCCTAATTAAAGTATAGG & $57^{\circ} \mathrm{C} / 8 \mathrm{~s}$ & $16 \mathrm{~S}$ rRNA & 104 \\
\hline $\begin{array}{l}\text { Gallus } \\
\text { gallus }\end{array}$ & $\begin{array}{l}\text { f-AGAGCTCGGCAAATGCAAA } \\
\text { r-GGCAGGGTCATGTCCG }\end{array}$ & GAACCTCTGGATAAAGGGCTTAAGCC & $50^{\circ} \mathrm{C} / 8 \mathrm{~s}$ & ATPase 8 & 99 \\
\hline Plant & $\begin{array}{l}\text { f-TGCAGTTAAAAAGCTCGTAG } \\
\text { r-GAAACTTCTTTAATCTCACG }\end{array}$ & CCCGAAGCCGGACCTAGAAAC & $50^{\circ} \mathrm{C} / 6 \mathrm{~s}$ & $\begin{array}{l}\text { 18S rRNA } \\
(\text { Zea mays) }\end{array}$ & 159 \\
\hline
\end{tabular}


the reverse primer in $O$. aries were labelled at the $3^{\prime}$ with Thymine fluoresceine (iFL). Four species-specific probes were also designed and labelled with LC Red-640 at the $3^{\prime}$ end purchased from TIB Molbiol srl (Genova, Italy) (Table 1). Universal primers for plant mtDNA were used to verify the absence of inhibition in PCR (Table 1).

\subsection{Conventional PCR protocol}

Positive and negative DNA controls were included in all conventional PCR assays. DNA from feed samples contaminated with $0.2 \%, 0.5 \%$ and $1 \% \mathrm{MBM}$ were analyzed to measure the amplification efficiency of species-specific primers, Standard PCR were carried out in an Applied Biosystem 9700 thermal cycler. Reaction mix contained 10-50 ng of DNA, $1 \mathrm{U}$ of Taq Polymerase Platinum High Fidelity (Invitrogen, California USA), 1x Platinum High Fidelity buffer $(200 \mathrm{mM}$ Tris- $\mathrm{HCl}$ pH8.4, $500 \mathrm{mM} \mathrm{KCl}), 0.2 \mathrm{mM}$ each dNTPs, $1.5 \mathrm{mM} \mathrm{MgCl}_{2}$, and $10 \mathrm{pmol}$ of each primer in a $20 \mu \mathrm{l}$ final volume. The amplification profile was: i) initial denaturation at $94{ }^{\circ} \mathrm{C}$ for $2 \mathrm{~min}$; ii) 30 cycles at $94{ }^{\circ} \mathrm{C}$ for $10 \mathrm{~s}$, annealing temperature and time according to species (Table 1), extension: $72{ }^{\circ} \mathrm{C}$ for $15 \mathrm{~s}$; iii) final extension at $72{ }^{\circ} \mathrm{C}$ for $2 \mathrm{~min}$. Amplified products were tested by electrophoresis in a $2 \%$ agarose gel and visualized by ethidium bromide staining.

\subsection{Real Time PCR}

Real Time PCR (RT-PCR) was performed in a Light-Cycler amplifier (Light-Cycler, Roche, Germany) using a FRET detection system. Template DNA was amplified in a total reaction volume of $15 \mu$. The RT-PCR mixture comprised $1 \times$ PCR buffer (200 mM Tris- $\mathrm{HCl} \mathrm{pH} \mathrm{8.4,} 500 \mathrm{mM} \mathrm{KCl}) 4 \mathrm{mM} \mathrm{MgCl}_{2}$, $0.2 \mathrm{mM}$ each dNTPs, 10 pmol of each primer, 4 pmol of each labelled probe and $1 \mathrm{U}$ of Platinum high fidelity Taq polymerase (Invitrogen, California USA). The amplification profile initiated by a 2 min incubation at $94{ }^{\circ} \mathrm{C}$, followed by 40 cycles at $94{ }^{\circ} \mathrm{C}$ for $10 \mathrm{~s}$, annealing temperature and time differing among species (Table 1), $72{ }^{\circ} \mathrm{C}$ for $15 \mathrm{~s}$. Serial dilutions of DNA from heat treated and untreated meat were amplified to construct the standard curve for each target species. The $C_{\mathrm{t}}$ (crossing threshold) values, defined as the number of cycles needed to reach a defined relative fluorescence level (calculated by the Roche Light-Cycler Software 4.0), were plotted as a linear function of the Log of DNA concentration. A melting curve was plotted at the end of each run, to verify the specificity of the amplification product. For each experiment, the reaction efficiency for standard and sample curves was measured as described in the Roche Light-Cycler manual. Following Real Time PCR, products were also electrophoresed in a $2 \%$ agarose gel and visualized by ethidium bromide staining.

\section{Results}

\subsection{Primer species-specificity}

Primer pairs designed for the identification of bovine, ovine swine and chicken were tested for their species- specificity by conventional PCR. Amplification conditions were optimized in each species and verified in three independent laboratories. The test of primers-specificity against a panel of eleven animal species was negative with the exclusion of the corresponding specie (data not shown). Primer pairs resulted highly species-specific within the panel of species investigated, detecting only B. taurus, G. gallus and $O$. aries respectively. The swine-specific primers detected both domestic and wild boar. No amplification was observed when primers were tested on twelve plant species frequently found in feedstuffs (data not shown). PCR assays performed on feed samples contaminated by $0.2 \%, 0.5 \%$ and $1 \% \mathrm{MBM}$, showed a high sensitivity, detecting contaminations as low as $0.2 \%$ (Fig. 1 ).

\subsection{Light-Cycler RT-PCR assay}

\subsubsection{Construction of standard curves on animal and MBM DNA}

To test the system, and assess the range of RT-PCR linearity, standard curves were constructed on genomic DNA, on MBM DNA from each target species. Cycle threshold $\left(C_{\mathrm{t}}\right)$ values from serial dilutions of genomic DNA were plotted versus the logarithm of the DNA concentration (Fig. 2A). Standard curves of bovine and ovine genomic DNAs had a linear quantization

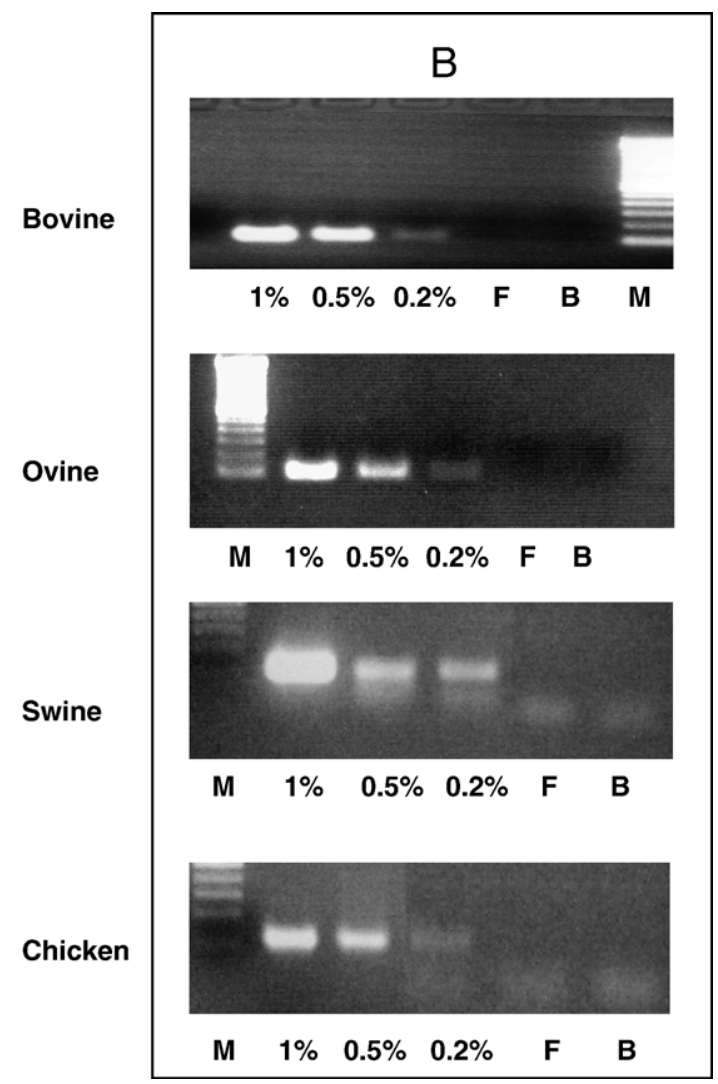

Fig. 1. Sensitivity of conventional PCR amplifications, analysed by agarose gel electrophoresis, using specific primers for bovine, ovine, swine and chicken to detect species-species DNA sequence in contaminated eedstuff containing $1 \%$, $0.5 \%$ and $0.2 \%$ of each MBM. Lane F: not contaminated feedstuff DNA; Lane M 100 bp ladder, Lane B: negative control. 
A

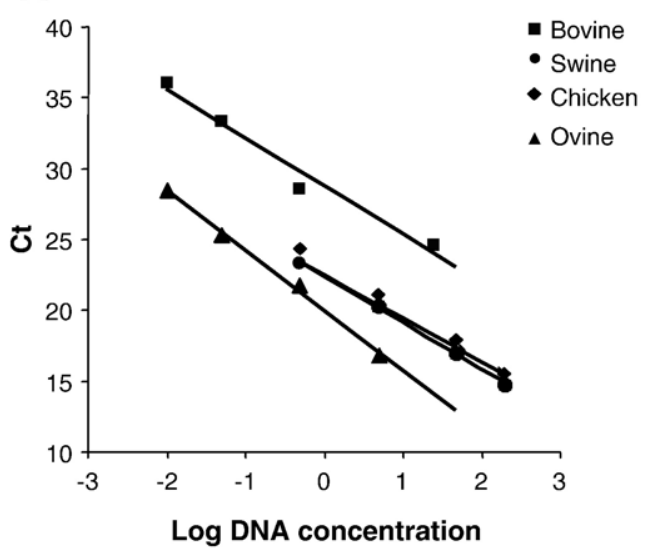

B

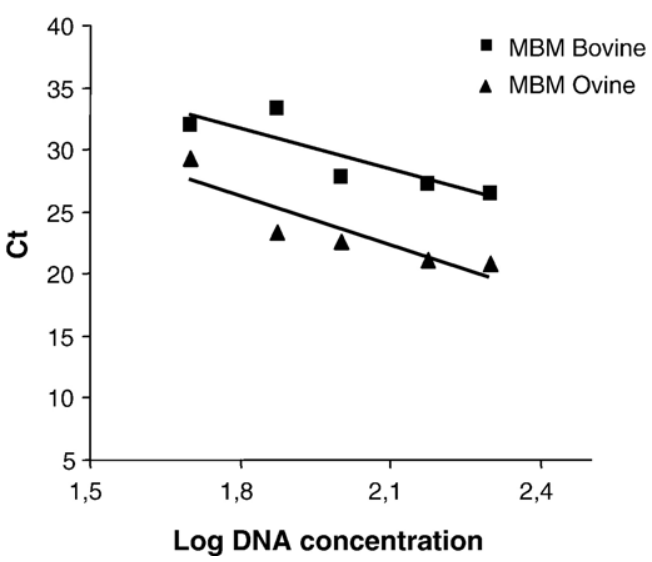

C

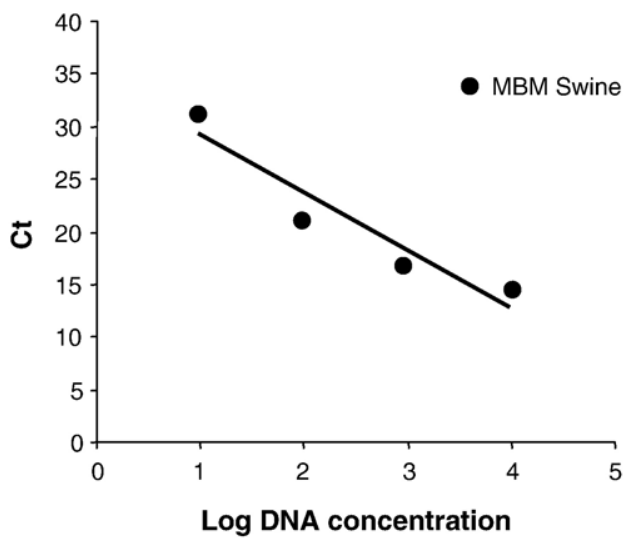

D

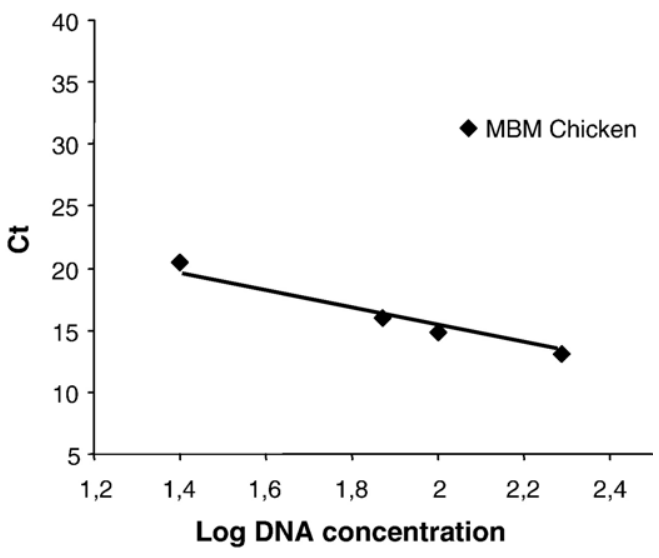

Fig. 2. Standard curves obtained plotting cycle threshold $\left(C_{\mathrm{t}}\right)$ values versus the logarithm of known different concentration of A) bovine (square), swine (dot), chicken (diamond) and ovine (triangle), genomic DNA; B) bovine and ovine MBM DNA; C) swine MBM DNA D) chicken MBM DNA.

range between 0.05 and $50 \mathrm{ng}$ and between 0.01 and $5 \mathrm{ng}$, respectively (Fig. 2A). Chicken and swine genomic DNA had a linear quantization between 0.5 and $200 \mathrm{ng}$, (higher dilutions for swine not reported) (Fig. 2A). Standard curves of bovine and ovine MBM (heath treated) DNAs had a linear quantization range between 50 and $200 \mathrm{ng}$ (Fig. 2B) while the swine and chicken MBM DNA showed a good linearity in a range between $5 \mathrm{fg}$ and $0.5 \mathrm{ng}$ and between 25 and $200 \mathrm{ng}$, re-

Table 2

Cycle threshold $\left(C_{\mathrm{t}}\right)$ values obtained in real time RT-PCR (Light-Cycler) for the detection of bovine, ovine, swine and chicken DNAs on dilution of DNA extracted from feedstuff sample contaminated with $0.5 \%$ of MBM from the four animal species

\begin{tabular}{|c|c|c|c|c|}
\hline $\begin{array}{l}\text { Feedstuff } \\
0.5 \% \mathrm{MBM}\end{array}$ & $\begin{array}{l}\text { Bovine } \\
\text { probe }\end{array}$ & $\begin{array}{l}\text { Ovine } \\
\text { probe }\end{array}$ & $\begin{array}{l}\text { Swine } \\
\text { probe }\end{array}$ & $\begin{array}{l}\text { Chicker } \\
\text { probe }\end{array}$ \\
\hline ng & $C_{\mathrm{t}}$ & $C_{\mathrm{t}}$ & $C_{\mathrm{t}}$ & $C_{\mathrm{t}}$ \\
\hline 5 & & 36.00 & & \\
\hline 25 & $>46.00$ & 29.60 & 31.92 & - \\
\hline 50 & 42.84 & 26,75 & 27.36 & - \\
\hline 100 & 39.60 & - & 27.71 & 27.99 \\
\hline 150 & 39.06 & - & 25.33 & 26.85 \\
\hline 200 & 37.63 & - & 23.05 & 25.96 \\
\hline
\end{tabular}

spectively (Fig. 2C and D). Regression coefficients $(r$ ) ranged from 0.80 to 1.00 in all experiments. Melting curve profiles of PCR products indicated the amplification of a single PCR amplicon.

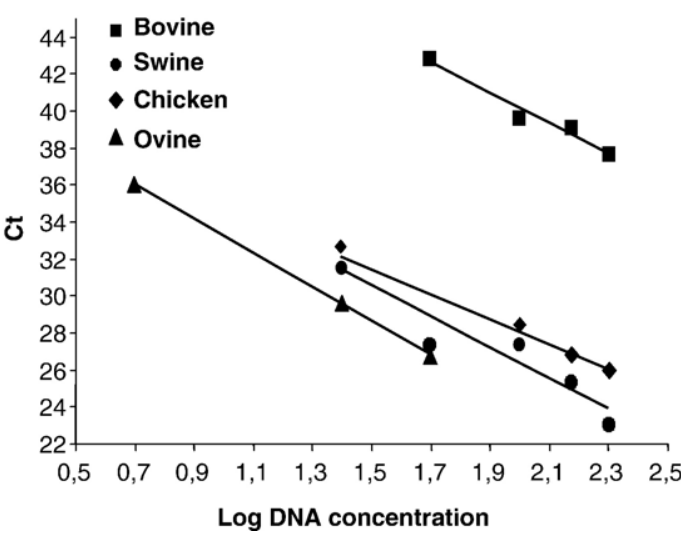

Fig. 3. Regression data obtained by plotting cycle threshold $\left(C_{\mathrm{t}}\right)$ values versus the logarithm of known different concentration of DNA extracted from feedstuff sample contaminated together with $0.5 \%$ heath treated MBMs of the four species reported. The data are obtained with real time PCR with bovine (square), swine (dot), chicken (diamond) and ovine (triangle), specific primers and probes. 


\subsubsection{Test on contaminated feedstuff}

To determine the efficiency and linear range of quantization of bovine, ovine, swine and chicken specific primers, dilutions $(200,150,100,75,50,25$ and $5 \mathrm{ng})$ were prepared from DNA extracted from feed samples contaminated with $0.5 \% \mathrm{MBM}$ of the four species (Table 2). The curve obtained for each speciesspecific primer show a good correspondence between the dilutions and the $C_{\mathrm{t}}$ values (Fig. 3). The increase of the slope indicates a lower efficiency in terms of cycles necessary to detect the presence of specific DNA. Swine and bovine primers showed a good efficiency to detect the presence of specific DNA on the multiple contaminated feedstuff. Chicken primers were slightly less efficient at higher dilutions of the contaminated feedstuff, while ovine primers were able to detect ovine MBM contamination at a dilution corresponding to as low as 5 ng of total DNA (Table 2). Universal Plant primers were used as control of amplificability and absence of inhibition effect on PCR (data not shown).

\section{Discussion}

The demonstrated BSE transmission through animal feedstuffs contaminated with the prion protein, has resulted in numerous efforts to develop and validate methods for detection of prohibited animal material in feedstuffs. In this study, we assessed the performance of new PCR primers specific for bovine, ovine, swine and chicken in detecting and quantifying MBM contamination in feedstuffs. Conventional PCR results showed a high specificity of primers when a panel of genomic DNA from mouse, dog, goat, buffalo, deer, horse and wild boar were used as negative control. Species-specific primers detected only B. taurus, S. scrofa, G. gallus and $O$. aries species. However swine primer showed positive amplification with genomic DNA from wild boar. Indeed this was expected, since swine and wild boar are a same species and cannot be distinguished through the analysis of mitochondrial DNA (Larson et al., 2005). Species-specific PCR based assays have previously been reported for the identification of animal derived material in feedstuffs by amplifying mtDNA genes as cytochrome $b$, ATPase 8, ATPase 6 and $12 \mathrm{~S}$ rRNA (Chen, Wen, Ding, Kao, \& Kuo, 2003; Herman, 2001; Myers et al., 2001; Rodríguez et al., 2004). Nevertheless, primers here reported were designed to obtain amplicons smaller than $120 \mathrm{bp}$, detectable in highly degraded material (Frezza et al., 2003; Chiappini et al., 2005). Indeed, during feedstuffs preparation, the DNA is degraded due to the hyperbaric treatment applied $\left(133{ }^{\circ} \mathrm{C} / 3\right.$ bar for $\left.20 \mathrm{~min}\right)$.

The sensitivity of species-specific primers on feed samples containing $0.2 \%, 0.5 \%$ and $1 \%$ of bovine, ovine, swine and chicken MBM was examined by conventional PCR. The detection limit was lower than $0.2 \%$ contamination for all primers, indicating a high sensitivity of this method when comparing it with the results obtained by Chen et al. (2003) and Rodríguez et al. (2004), who reported a detection limit of $1 \%$.

RT-PCR methods' aim is to reach an adequate sensitivity in the detection and quantification of very low amounts of degraded DNA from banned species in feedstuffs (Bellagamba, Comincini, Ferretti, Valfre, \& Moretti, 2006; Krcmar \& Rencova, 2001; Mendoza-Romero et al., 2004). In this study an LC PCR assay was performed, to quantify genomic and MBM DNA from bovine, ovine, swine and chicken species. The melting curve constructed from RT-PCR confirmed the specificity of our primers. The assays using species-specific primers on bovine, ovine, swine and chicken genomic DNA permitted a linear quantization range starting from $0.05,0.01$ and $0.5 \mathrm{ng}$, respectively. These levels of sensitivity do not reflect the actual limit of species detection in this RT-PCR system, but the starting concentrations at which these species showed a linear range for quantification. Mendoza-Romero et al. (2004), reported that standard curves are less reproducible using less than $8.5 \mathrm{fg}$ of DNA. Accordingly, we have observed that as little as $5 \mathrm{fg}$ of swine and chicken genomic DNA, still produced a detectable fluorescent signal, however at this concentration results were poorly reproducible (data not shown). Sensitivity levels observed in MBM DNAs were significantly different compared to those in genomic DNAs previously described. Interestingly while they resulted in lower levels in swine (5 fg of MBM DNA), they were higher in chicken (25 $\mathrm{ng}$ ), ovine and bovine (50 $\mathrm{ng}$ ), this probably depending on the different performance of the primers.

Quantitative RT-PCR assay was carried out also in a single feedstuff contaminated with $0.5 \%$ MBM from bovine, ovine, swine and chicken, to evaluate results in the case of complex contaminations. Our results indicate a high efficiency of ovine primers, detecting their target until the higher dilution (5 ng of total DNA, corresponding to about $25 \mathrm{fg}$ of target DNA). According to previous results, a lower efficiency was observed at the same dilution using chicken primers on a same contaminated feed. Bovine and swine primers showed a good efficiency to detect the presence of specific DNA on the multiple contaminated feedstuff. The direct comparison of the different species-specific primers shows absence of interference among DNAs from different species observed as a linear correspondence to the progressive dilutions.

The RT-PCR is still the only species-specific technique available to quantify and detect sources of animal protein, (Bellagamba et al., 2006; Fumière, Dubois, Baeten, von Host, \& Berben, 2006; Krcmar \& Rencova, 2005). Used in combination with complementary techniques such as inmunoassay and spectroscopy methods, it remains an important part of the approach used to determine the origin of animal protein present in feeds (Fumière et al., 2006). The species-specific PCR assays evaluated in this study have potential as molecular tools that can be used for rapid and routine detection and quantization of bovine, ovine, swine and chicken MBM present in feedstuffs. We conclude that the occasional contamination (not fraudulent) of feedstuff can be efficiently quantified by PCR and RT-PCR methods because the MBM materials are processed at the pressure and temperatures requested by the $\mathrm{EU}$ guidelines. However in case of fraudulent contamination the temperature and pressure treatments are unknown therefore only qualitative analysis can be performed because a reference material is absent. 


\section{Acknowledgements}

We thank the TIB Molbiol srl (Genova, Italy) for the high competent technical assistance. Part of the work was supported by the Istituto Zooprofilattico Sperimentale del Lazio e Toscana (Italy), by the grant ISZLER 2001/02, "Ricerca corrente1\%" from the Italian ministry of Health (Ist. Zooprofilattico Sperimentale per l'Emilia Romagna e Lombardia) and by the subcontract of the European grant n.G6RD-CT2000-00414 STRATFEED.

\section{References}

Ansfield, M., Reaney, S., \& Jackman, R. (2000). Production of a sensitive immunoassay for detection of ruminant and porcine proteins, heated to $>130{ }^{\circ} \mathrm{C}$ at 2.7 bar, in compound animal feedingstuffs. Food and Agricultural Immunology, 12, 237-384.

Baeten, V., von Holst, C., Garrido, A., Vancutsem, J., Michotte Renier, A., \& Dardenne, P. (2005). Detection of banned meat and bone meal in feedstuffs by near-infrared microscopic analysis of the dense sediment fraction. Analytical and Bioanalytical Chemistry, 382, 149-157.

Bellagamba, F., Comincini, S., Ferretti, L., Valfre, F., \& Moretti, V. M. (2006). Application of quantitative real-time PCR in the detection of prion-protein gene species-specific DNA sequences in animal meals and feedstuffs. Journal of Food Protection, 69, 891-896.

BSE Inquiry. (2000). The BSE Inquiry report, vol 1. Findings and conclusions, chapter 12. Science and research, paragraph 1122.

BSE Inquiry. (2000). The BSE Inquiry report, vol 2. Science, chapter 3. The nature and cause of BSE, paragraph 3123.

Chen, Y. H., Wen, C., Ding, S., Kao, C., \& Kuo, T. (2003). Detecting meat-andbone meal in ruminant's feeds by species-specific PCR. Journal of Animal and Food Sciences, 12, 851-860.

Chiappini, B., Brambilla, G., Agrimi, U., Vaccari, G., Aarts, H., Berben, G., et al (2005). Real-time polymerase chain reaction approach for quantitation of ruminant-specific DNA to indicate a correlation between DNA amount and meat and bone meal heat treatments. Journal of AOAC International, 88, 1399-1403.

Commission Decision 94/381/EC of, 27 June 1994 concerning certain protection measures with regard to bovine spongiform encephalopathy and the feeding of mammalian derived protein. Official Journal of the European Communities L $172,07.07 .94$, p. $23-24$.

Commission Decision 94/382/EC of 27 June 1994 on the approval alternative heat treatment systems for processing animal waste of ruminant origin, with a view to the inactivation of spongiform encephalopathy agents. Official Journal of the European Communities L 172, 07/07/1994 p.0025-0028.

Department of Agricultural, Food and Rural Development http://www.irlgov.ie/ daff/bse/bse.htm

Dalmasso, A., Fontanella, E., Piatti, P., Civera, T., Rosati, S., \& Bottero, M (2004). A multiplex PCR assay for the identification of animal species in feedstuffs. Molecular and Cellular Probes, 18, 81-87.

EC (2002). Regulation 1774/2002 of 10 October 2002 of the European Parliament and of the council. Laying down health rules concerning animal by-products not intended for human consumption. Official Journal of the European Communities, L 273/1 10/10/2002 p.0001-0095.

Frezza, D., Favaro, M., Vaccari, G., von-Holst, C., Giambra, V., Anklam, E., et al. (2003). A competitive polymerase chain reaction-based approach for the identification and semiquantification of mitochondrial DNA in differently heat-treated bovine meat and bone meal. Journal of Food Protection, 66, 103-109.

Fumière, O., Dubois, M., Baeten, V., von Host, C., \& Berben, G. (2006). Effective PCR detection of animal species in highly processed animal products and compound feeds. Analytical and Bioanalytical Chemistry, 385, 1045-1054.

Gizzi, G., van Raamsdonk, L., Baeten, V., Murray, I., Berben, G., Brambilla, G., et al. (2003). An overview of tests for animal tissues in feeds applied in response to public health concerns regarding bovine spongiform encephalopathy. Revue des Sciences Techniques, 22, 311-331.

Herman, L. (2001). Determination of the animal origin of raw food by speciesspecific PCR. Journal of Dairy Research, 68, 429-436.

Kim, S., Huang, T., Seymour, T., Wei, C., Kempf, S., Bridgman, C., et al. (2005). Development of immunoassay for detection of meat and bone meal in animal feed. Journal of Food Protection, 68, 1860-1865.

Krcmar, P., \& Rencova, E. (2005). Quantitative detection of species-specific DNA in feedstuffs and fish meals. Journal of Food Protection, 68, 1217-1221.

Krcmar, P., \& Rencova, E. (2001). Identification of bovine-specific DNA in feedstuffs. Journal of Food Protection, 64, 117-119.

Larson, G., Dobney, K., Albarella, U., Fang, M., Matisoo-Smith, E., Robins, J., et al. (2005). Worldwide phylogeography of wild boar revels multiple centers of pig domestication. Science, 307, 1618-1621.

Lopez-Andreo, M., Lugo, L., Garrido-Pertiera, A., Prieto, M., \& Puyet, A. (2005). Identification and quantitation of species in complex DNA mixtures by Real Time polymerase chain reaction. Analytical Biochemistry, 339, 73-82.

Mendoza-Romero, L., Verkaar, E., Savelkoul, P., Catsburg, A., Aarts, J., Buntjer, J., et al. (2004). Real-Time PCR detection of ruminant DNA. Journal of Food Protection, 67, 550-554.

Momcilovic, D., \& Rasooly, A. (2000). Detection and analysis of animal materials in food and feed. Journal of Food Protection, 63, 1602-1609.

Myers, M., Friedman, S., Farrell, D., Dove-Pettit, D., Bucker, M., Kelly, S., et al. (2001). Validation of a polymerase chain reaction method for the detection of rendered bovine-derived materials in feedstuffs. Journal of Food Protection, 64, 564-566.

Myers, M., Yancy, H., Araneta, M., Armour, J., Derr, J., Hoostelaere, L., et al. (2006). Validation of a PCR-based method for the detection of various rendered materials in feedstuffs using a forensic DNA extraction kit. Journal of Food Protection, 69, 205-210.

Rodríguez, M., Garcia, T., Gonzalez, I., Asensio, L., Hernandez, P., \& Martin, R. (2004). PCR identification of beef, sheep, goat, and pork in raw and heattreated meat mixtures. Journal of Food Protection, 67, 172-177.

Tartaglia, M., Saulle, E., Pestalozza, S., Morelli, L., Antonucci, G., \& Battaglia, P. (1998). Detection of bovine mitochondrial DNA in ruminant feeds: A molecular approach to test for the presence of bovine-derived materials. Journal of Food Protection, 61, 513-518.

Taurai, T., Schumacher, S., \& Roger, S. (2005). Conventional and real-time PCR-based approaches for molecular detection and quantitation of bovine species material in edible gelatine. Journal of Food Protection, 68 , 2420-2426.

von Holst, C., Unglaub, W., \& Anklam, E. (2001). Post process product control of rendering plant sterilisation conditions by ELISA. Journal of $A O A C$ International, 84, 1793-1799.

Yancy, H. F., Mohla, A., Farrell, D., \& Myers, M. (2005). Evaluation of a rapid PCR-based method for the detection of animal material. Journal of Food Protection, 68, 2651-2655. 